\title{
Market Behavior in Land Value According to Water Accessibility - Case Study: Three Rural Properties in México
}

\author{
Estefanía Flores-Benítez ${ }^{1}$, Miguel Galvan-Ruiz ${ }^{2} \&$ Eusebio Ventura-Ramos ${ }^{1}$ \\ ${ }^{1}$ Facultad de ingenieria División de Investigación y Posgrado, Facultad de Ingeniería, Universidad Autónoma de \\ Querétaro, Querétaro, México \\ ${ }^{2}$ CETIS 105-SEP, Km 3.5 Carretera a Tlacote, Querétaro, México \\ Correspondence: Estefania Flores-Benítez, Facultad de ingenieria División de Investigación y Posgrado, \\ Facultad de Ingeniería, Universidad Autónoma de Querétaro, CU Cerro de las Campanas 76010, Querétaro, \\ México. E-mail: estefaniaflores@yahoo.com
}

Received: May 18, 2013 Accepted: June 16, 2013 Online Published: June 25, 2013

doi:10.5539/jgg.v5n3p55 URL: http://dx.doi.org/10.5539/jgg.v5n3p55

\begin{abstract}
Water availability is a key factor for rural properties in semiarid areas. Urbanization, industrial, droughts and climate change are reducing water for agriculture. As accessibility declines, water becomes a critical factor defining the price of land. Pricing rural land generally includes several factors. However, water is not considered an explicit factor in the existing valuation methods. The objective of this study was to evaluate the differential cost of rural land due to the availability of water, by considering at different methods that are used to value rural properties in Mexico: valuation of physical mass appraisal, comparable method, profits productivity method, and income capitalization method. The study was carried out in three sites of semiarid Central Mexico: El Toreador, Luz de María and Zamarripa, all located in the State of Guanajuato. The results indicated that the price of land decreased strongly, due the lack of water availability independently of the valuation method used. The decrease in land price is also linked to other factors, such as the market value and location.
\end{abstract}

Keywords: rural property valuation, water availability, water resources

\section{Introduction}

The United Nations officially adopted water as a human right (United Nations General Assembly, 2010). However, it is widely accepted that this resource needs to be treated as a valuable and finite commodity; the provision of water rights become critical (Zwarteveen, 1997; Bocquet et al., 2008). The theory of charging a realistic price for water use is based on the fact that economic behavior would regulate prices (Friedman, 1990). A reasonable price for this will immediately generate behavioral changes that no public relations campaign can produce (Sarmiento, 2006). As a high priority in dealing with the problem of water scarcity, the effect of water pricing policy still remains a controversial issue (Han \& Zhao, 2007).

The economic value of water was recognized in 1992 in The Dublin Statement on Water and Sustainable Development: "Water has an economic value in all its competing uses to which it is intended, and should be recognized as an economic good". Under this principle, it is vital to recognize first the basic right of all human beings to have access to clean water and sanitation at an affordable price. Ignorance in the past, in regards to the economic value of water, has led to wasteful use of this resource with adverse effects on the environment (United Nations, 1992).

Water use, directly affects the value of the properties (Palmquist, 2005; MacDonald et al., 2010). However, the process of valuation of agricultural lands is based on the origin of market principles and the elements related to it, so, water is considered as a factor only in an indirectly way. As any consumer product, the rural properties are influenced by economic and political solutions coming from the urban development pressure, different types of land ownership and speculation (by the value in use) in the market itself (French, 2003). Additionally, endogenous price volatility cannot be ignored, especially given that it leads to different implications in terms of policies and courses of action, both public and private (Mitraa \& Boussardb, 2012).

In practical terms, the value of a rural property increases proportional to the total irrigated area on it and, based on this relationship, the land owners have the option of implementing water conservation practices to improve 
the efficiency in the use of this resource (Baylis et al., 2002). However, this alternative has not been implemented extensively and, although policies of water pricing are affected by it, this also affect a large number of other important issues widely useful (Chettri \& Venkatesan, 1983; Varela-Ortega et al., 1998; Gómez \& Riesgo, 2004; Shively, 2001). The current method used in Mexico to value rural property does not reflect directly the availability of this resource; nevertheless, it is always relatively implicit in other variables.

The purpose of this study was to evaluate the differential value of rural properties affected by the availability of water, using the valuation methods of Physical Characteristics of Rural Land (Mass Appraisal), Comparable Market Methods, Profits Productivity Method and Income Capitalization Method, as well as identifying key indicators related to water resource availability in the valuation of rural property (Flores-Benitez et al., 2011).

\section{Method}

\subsection{Definition: Subjects under Study}

Experienced land owners, representative of the productive systems of northern Guanajuato State region were selected as potential subjects of this study. Three of them provided their confidential financial information so that the four methods of land valuation through water were applied in hypothetical conditions of no available water.

\subsection{Sites Description}

Considering that the productive characteristics are unique to each rural property, the contrasts of this study were planned according to the use and availability of water; short description of the study sites are as follows, all located in the municipality of San Luis de la Paz:

A. Luz de María site. Located at X=347.000 Y=2,535,500 UTM coordinates and an altitude of 2030 masl. this $166 \mathrm{Ha}$ property has rangeland with 28 Ha pasture and sheep production (Figure 1), with a well water concession of $2400 \mathrm{~m}^{3}$ per hectare. Litosol is the predominant type of soils. The climate is semi-arid with summer rainfall of approximately $400 \mathrm{~mm}$. Average annual temperature ranges between 12 and $18^{\circ} \mathrm{C}$.

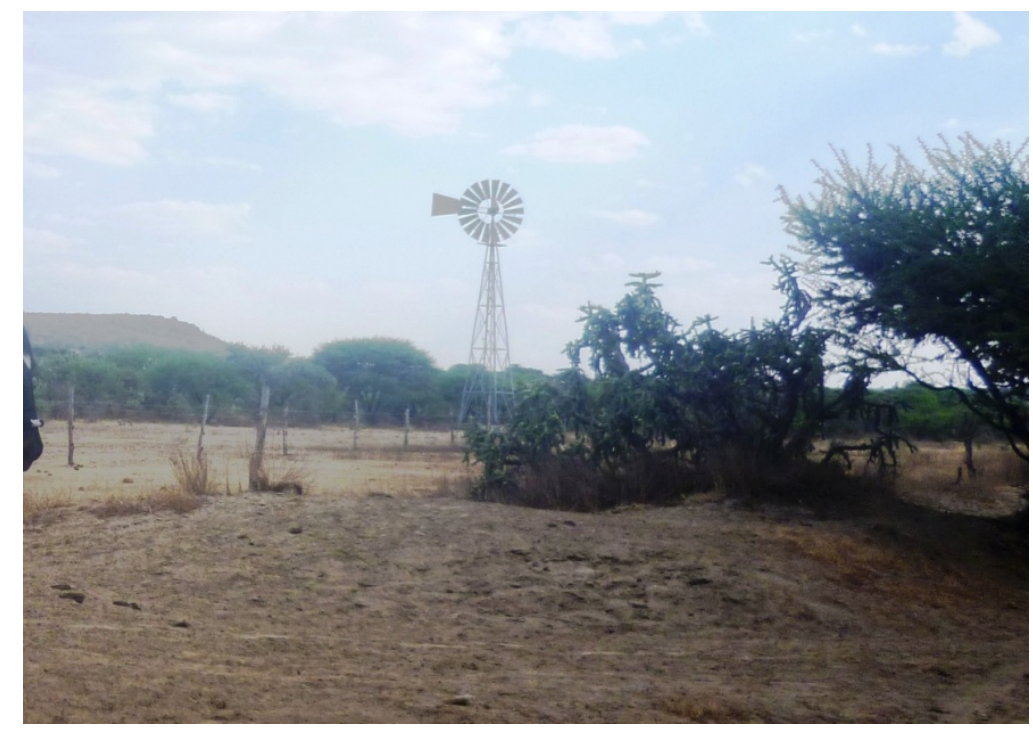

Figure 1. Panoramic view of the Luz de Maria site. Description A, above

B. El Toreador site. Located at $X=341.000$ and $Y=2,360,000$ UTM coordinates at an altitude of 2020 masl. This 284-ha site mainly for intensive agricultural and agro-industrial land used, dedicated to the cultivation of vegetables (lettuce, broccoli, chili pepper, cucumber, tomatoes, asparagus) and finally for storage and export (Figure 2). This property has a well water concession of $6000 \mathrm{~m}^{3}$ per hectare. The predominant soil type is Phaeozem. The climate is classified as semi-arid with an average rainfall of about $400 \mathrm{~mm}$ and average annual temperature between 12 and $18^{\circ} \mathrm{C}$. 


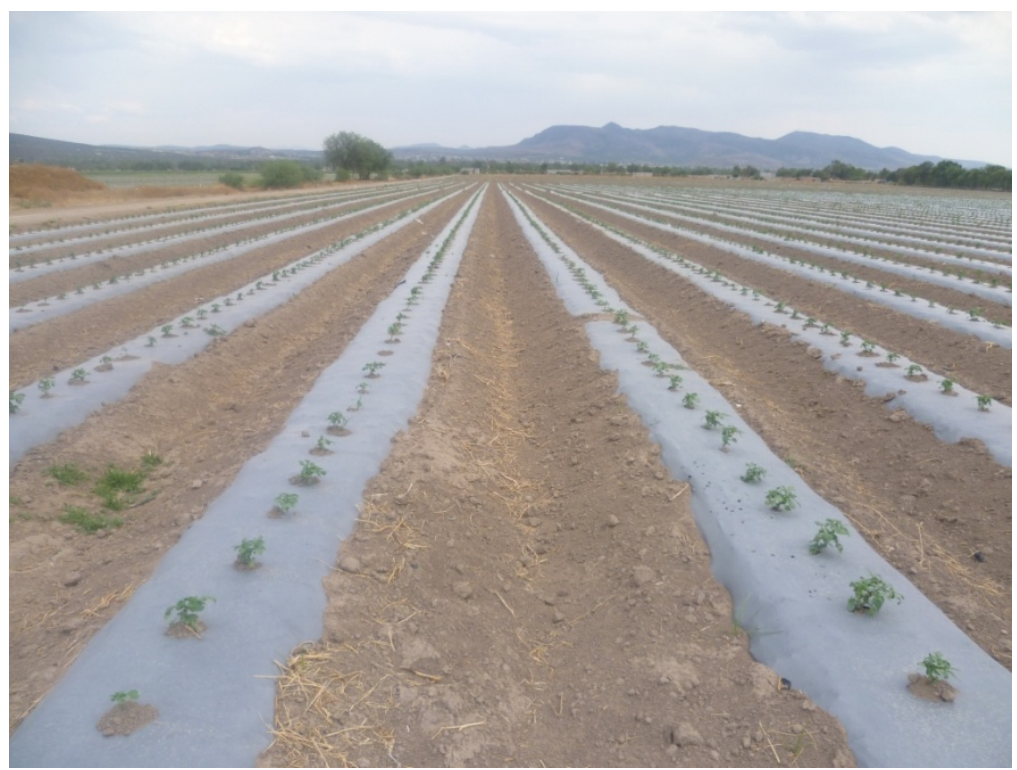

Figure 2. Panoramic view of the El Toreador. Description B, above

C. Hacienda Zamarripa site. Located at $X=352.500$ and $Y=2,365,000$ UTM, at an altitude of 2100 masl. This 100-ha site has a reforestation program and soil restoration, due to the heavy used of pasture and grazing, which led to a deterioration of soil and vegetation resources. Current use of agricultural land is sustainable and induced grassland (Figure 3). Water in this property comes from stream runoff, with an average of $300 \mathrm{~m}^{3}$ per hectare. Litosol soil type predominates and a semi-arid climate with an average rainfall of about $400 \mathrm{~mm}$ and annual temperature between 10 and $18{ }^{\circ} \mathrm{C}$.

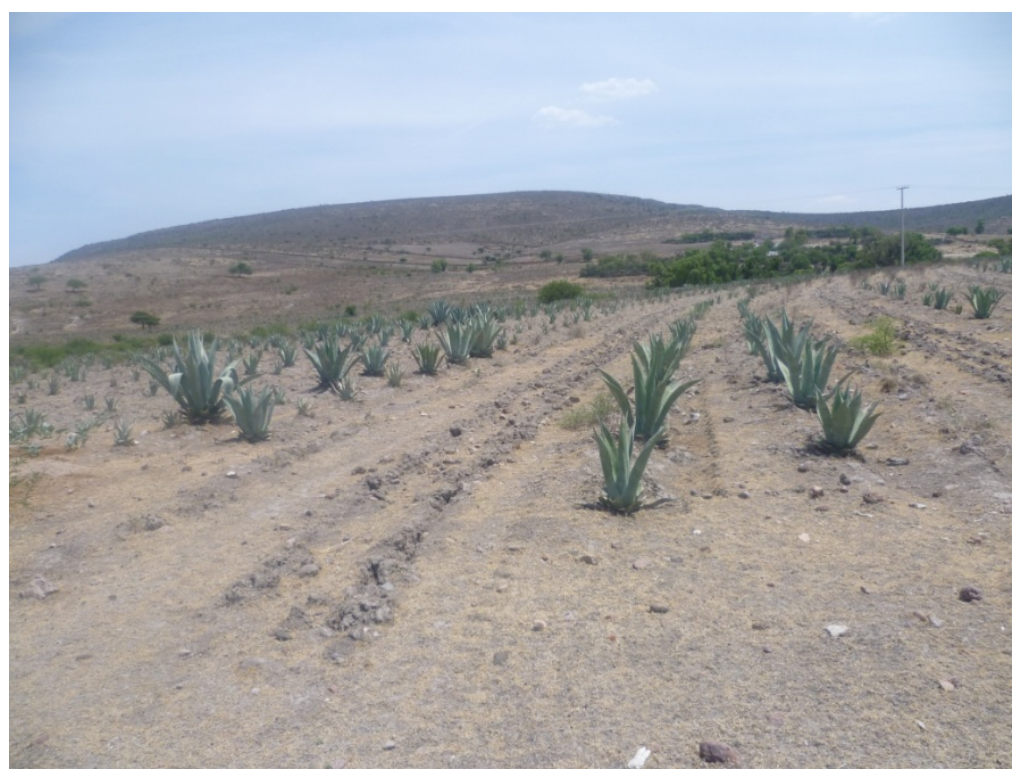

Figure 3. Panoramic view of the Zamarripa site.Description C, above

\subsection{Valuation Methods}

\subsubsection{Physical Properties of Rural Land Method (Mass Appraisal)}

This method consists in determining the physical characteristics of the land using thematic maps, such as the one produced by the National Institute of Statistics, Geography and Informatics (INEGI), as well as information obtained from field visits. Most of the information is obtained from the FAO Soil's Map at 1:50,000 scale, which describe the distribution of the predominant soil units, as well as physical characteristics, such as texture and 
topography. The landscape was analyzed using soil and topographical maps of the area. According to this method, knowing the land surface in combination with the above factors, a unit value per hectare can be determined (Gobierno del Estado de Querétaro, 2005; Asociación Nacional de Institutos Mexicanos de Valuación, A.C., 1996). Some important factors that characterized the site included: distance to the nearest urban area, soil depth, land use, potential use, erosion, topography and texture, stoniness, and a political category (Toy et al., 2002).

\subsubsection{Comparable Market Method}

This method is based primarily on the substitution principle, where the value of land is equivalent to other properties with similar characteristics. It is the most direct method available to assess the value of a property. It uses and compares statistics through homologation, to set the analysis and estimate the value of the subject studied (French, 2003). The homologation system uses correction coefficients of adjustment and analyze them with the values of the comparable (reference value), equating them with respect to the property under study, increasing or decreasing the coefficients depended on their characteristics (Ventolo \& Williams, 2008). This approach also uses market transactions that reflect the sensibility of market participants as well as some processes that involve the comparison as price lists and job postings (Jerome et al., 2000; French, 2003, 2007; Secretaría de Economía, 2007; Jefferies, 2009).

The theory behind this technique is based on the principle that the value of the property is directly related to the sales prices of comparable properties. The objective of this method is to estimate the Comparable Market Method value of the property in question. As mentioned before, the Market value is the most probable price a property can obtain by a sale that occurs in normal market conditions. The economic reasoning is that an informed buyer will not pay for a property more than the price of other comparable property, which is named the principle of substitution (Ventolo \& Williams, 2008). The compared sale prices represent the likely range of taxable value of the property. From this range, an estimated market value of the property can be determined. On the other hand, the main adjustments that are performed include those related to the physical characteristics of the property location, conditions of sale (motivation of buyer/seller and financial conditions) and time that operation will take to the date of sale.

\subsubsection{Investment and Profit Productivity Method}

This method of evaluation is a mathematical process of rationalization using a decision-making process. Sequences of actions are oriented to materialize into an investment. This increase guarantees that commercializing goods and services will produce a necessary income to return the investment therefore generating profits so that the investor is in accordance to the scheduled risks in the original project (Trigeorgis, 1993). Considering productivity, it is possible to make business transactions with an imminent potential and not only as independent investments of a property. The appraisal is based on the production potential it may have in a determined period of time, (normally a year), as well as on the costs to produce them, always analyzing the behavior in the historical database. It is a fact that water is not the only factor within the parameters of the market to establish its value and price (Sutton \& Constanza, 2002).

Usually the studies are analyzed using the method of evaluation of projects through Cost-Benefit, transforming into currency the different costs and benefits of an activity. We can estimate the accumulated financial impact of the investment. The Analysis of Cost-Benefit involves the following steps: 1) Determining the costs associated with each factor, 2) Adding the total costs for each proposed decision, 3) Determining through currency the benefits for each decision. 4) Placing the amounts of the total costs and benefits into the form of an equation where the benefits are the numerator and the costs are the denominator, and 5) Comparing the cost-benefit for different proposed decisions. The best solution, in financial terms, is the one with the highest ratio of cost-benefit (Smith, 1987). The different methods can be used to calculate the Cost-Benefit relation. Sophisticated methods consider the time amount of money as part of Cost-Benefit analysis. The time value of money, also known as the discount factor; it is simply a method used to convert the future value of money to present value. It is based on the premise that money today is worth more than money in a few years time due to the interest or gain it can accumulate.

\subsubsection{Income Capitalization Method}

In this method to obtain the price of a property, it is assumed that the capital, represented by the land and its improvements, is likely to increase its performance, and once capitalized, to work out the value of that land. The overall approach is in relation to the expected future performance of a real estate with its current value. The Capitalization method is a process which obtains the value of a good or right based on the amount of future net revenues or profits obtained during the economic life of the asset, and a rate based on productivity that involves all risks associated with the property or right in question. This approach reflects the principle of anticipation 
(French, 2003; Secretaría de Economía, 2007; Jefferies, 2009).

To determine the indicator value under this approach, it is necessary to quantify the profitability of the subject of valuation as well as the capitalization or discount rate applicable to the case. This approach is determined on the principles of better and more productive use and forward thinking. For purposes of determining the investment of capitalization of property we must determine whether the income is constant or variable, defining the characteristics of this variability in each case, as well as the economically productive life of the subject of valuation and the likely recovery value. This approach is applicable to elements linked to economic exploitation and for production units economically indivisible, but not for its separate components (Secretaría de Economía, 2007; IVSC, 2011).

Once the net operating income of a property is known, the percentage of the return on the investment expected by the buyer needs to be determined. This percentage is called the yield capitalization rate and it is determined by comparing the ratio of net operating income and the sales price of similar properties that have been sold at the time of performing the calculation. This technique is very useful with properties capable of producing an income. An investor determines the price to be offered by the potential acquisition of a property after carrying out the study of income that currently generates the property and determines the present value of the right to future income, according to the capitalization rate or percentage that an investor expects to receive (French, 2003; Ventolo \& Williams, 2008). The yield capitalization is a way to analyze the two components of the capitalization rate (return on equity and return on capital) separately. The method consists of selecting a rate for return on capital, called the discount rate or interest rate as well as a rate that represents the capital, called capital recovery. The discount rate takes into account the return that investors require to produce a profit, and can be found using the market extraction method which analyzes the discount rates of similar properties. It can also be found by the method of band investment in which the costs of providing the necessary funding to make the investment are multiplied by the required performance for input costs (Madureira et al., 2007).

\subsection{Compilation of Information}

This method consists, firstly, in geo-referencing all sites with GPS technology using UTM coordinates, determining the productivity data, obtained by knowing the exact timetable of production plans, product volumes, characteristics, and production costs. This information helps to compile the historical development of land productivity. The data is critical to recognize the viability of projects. Soil characteristics are important factors for agricultural productivity. This information is obtained according to the circumstances of each subject. The evaluation was done in field work and in the laboratory using INEGI cartography. A digital file is then created to visually and describes the characteristics and the evolution of the subjects under study.

\subsection{Definition of the Valuation Outline}

The appraisals were made according to statutory provisions set out in the legal framework for the presentation of the Banking Valuation, Credit Institutions Act Law (articles 46, section XXII, 48, 77 and 133), Bank of Mexico Law (article 26), and the Law of the National Banking and Securities Commission (NBSC) (article 2, 4, sections I and V).

\section{Results and Discussion}

The results of the different valuation methods for the three studied sites are presented in Table 1.

The studied subjects showed that water resources were different, despite the fact that they are located in the same basin; due to their own feasibilities and characteristics. The Toreador site (Figure 2) has sufficient water and adequate irrigation technology to irrigate throughout, while the Luz de Maria site (Figure 1) has just enough water for the cattle, and only a small volume for irrigation to induce grass area and lastly, the Zamarripa site (Figure 3), with a small stream, which only allows vegetation that need little water, such as agaves that need two irrigations during the dry season.

The political and social situations of the properties were also different, in term of accessibility, political status and its proximity to urban areas. These differences not only influenced their value but also their own natural characteristics.

The comparative analysis was performed under two conditions: At present, in which all properties have water (Current scenario), even though the availability was different, and a hypothetical condition with no water available for irrigation and all production depends only on rainfall. 
Table 1. Methods or valuation for two conditions in (\$ USD/Ha)

\begin{tabular}{|c|c|c|c|c|c|c|c|c|}
\hline \multirow{2}{*}{ Subject } & \multicolumn{2}{|c|}{ Physical properties Method } & \multicolumn{2}{|c|}{$\begin{array}{c}\text { Comparable Market } \\
\text { Method }\end{array}$} & \multicolumn{2}{|c|}{$\begin{array}{l}\text { Investment and Profit } \\
\text { Productivity Method }\end{array}$} & \multicolumn{2}{|c|}{$\begin{array}{c}\text { Income Capitalization } \\
\text { Method }\end{array}$} \\
\hline & $\begin{array}{l}\text { Current } \\
\text { scenario }\end{array}$ & $\begin{array}{l}\text { Hypothetical } \\
\text { scenario }\end{array}$ & $\begin{array}{l}\text { Current } \\
\text { scenario }\end{array}$ & $\begin{array}{l}\text { Hypothetical } \\
\text { scenario }\end{array}$ & $\begin{array}{l}\text { Current } \\
\text { scenario }\end{array}$ & $\begin{array}{l}\text { Hypothetical } \\
\text { scenario }\end{array}$ & $\begin{array}{l}\text { Current } \\
\text { scenario }\end{array}$ & $\begin{array}{l}\text { Hypothetical } \\
\text { scenario }\end{array}$ \\
\hline Toreador & 3125 & 746 & 581 & 119 & 2120 & 65 & 2540 & 77 \\
\hline $\begin{array}{l}\text { Luz de } \\
\text { María }\end{array}$ & 508 & 264 & 320 & 86 & 380 & 22 & 319 & 26 \\
\hline Zamarripa & 45 & 26 & 79 & 67 & 86 & 25 & 26 & 30 \\
\hline
\end{tabular}

The value in Mexican pesos per hectare obtained in the Current scenario for each rural property was as follows; \$3125 USD/Ha for the Toreador site, \$508 USD/Ha for the Luz de María site, and \$45 USD/Ha for the Zamarripa site. The differences between are related mainly to the current availability of water and consequently productivity. Also the differences are related to accessibility and distances from urban areas, which affect their applicable value. Additionally, the difference in prices are also related to other influential factors such as the depth and use of the soil, agricultural capacity, erosion, stoniness and texture.

In the hypothetical condition, the values obtained were \$26 USD/Ha for the Zamarripa site, \$264 USD/Ha for the Luz de Maria site, and \$746 USD/Ha for the Toreador site. Our observations showed that the relative magnitude of the values maintain the same order as the current condition, which demonstrates that the properties are affected by the same factors in same direction and at different ratios.

The settings for the hypothetical condition of each property are made independently, without there being a proportion of the declines among them. It is also noted that decrease in water as whole on each site, and the current situation, is in different amounts with different characteristics on each subject.

If considering the current condition as $100 \%$ in the case of the Toreador property, from current condition to the hypothetical scenario, the value went down from \$3125 USD/Ha to \$746 USD/Ha, which represents a devaluation of $76 \%$. In the case of the Luz de Maria property, the absolute reduction was \$243 USD/Ha, which represents $48 \%$ devaluation. Finally, of the Zamarripa property, the absolute reduction was \$20 USD, which resulted in a reduction of $44 \%$ of its value. Specifically, the difference can be associated with the availability presence of water as a resource. Although in general all three properties decreased in value in the absence of water, those with a greater presence of water will suffer larger reductions, both absolute and relative, in the hypothetical condition of the absence of water. This demonstrates that the lack of water is closely related to the agricultural capacity of the property.

The assessment through the Comparative Market Method Value shows the desirability for the market, and considers, among other factors, the presence of water and the location as substantial elements. The results from the analysis of Market Value are the values corresponding to a transaction in the open market for properties with existing features or for subjects with hypothetical characteristics. This method is used to define the final value conclusion in most of the appraisals made for rural properties, and generally represents the transaction value.

In the case of the Comparable Market Methods the current and the hypothetical condition of the properties were considered according to their existing characteristics, under the assumption that in this condition the properties would not count on the availability of water. For the assume properties under a hypothetical rainfed condition, various factors were homologated such as water availability, and climate in different conditions.

The values obtained for the three sites in the current state were $\$ 581 \mathrm{USD} / \mathrm{Ha}$ for the Toreador site, $\$ 320$ USD/Ha for the Luz de María site, and \$79 USD/Ha for the Zamarripa site. The differences among these values corresponded first directly to the availability of water, this difference is also related to the production capacity of each property according to factors such as slope and water availability, proximity of the closest urban zone, which is directly related to the feasibility of each property according to market research study.

In general, the values obtained by this method for the current condition followed the same trend in terms of relative magnitude in relation to the valuation physical method for Mass Appraisal, although the absolute magnitude values were different. In the hypothetical condition, values generated by this method were as follows: \$119 USD/Ha for Toreador site, \$86 USD/Ha for Luz de Maria site, and \$67 USD/Ha for Zamarripa site. The difference between the two conditions was significant and reflected the effect of water availability and other factors directly linked. In fact, in the case of the Toreador site, the value for the current condition is approximately $80 \%$ greater than in the hypothetical condition without water. In the Luz de Maria site, the value 
determined for the current condition was $70 \%$ higher than the hypothetical condition. Finally, the value for the Zamarripa site was $15 \%$ higher than in the hypothetical situation. This variation is attributed to an increased production capacity resulting from the availability of water. Although the method does not consider the provision of water directly, indirectly, it indeed reflects the market feasibility due to a larger production capacity.

According to the principle of this method the buyer is not willing to pay more for properties with lower availability of water for production. The market recognizes the characteristics of the properties, considering two separate market segments for the two study conditions: As properties under irrigation and production, and under a properties rainfed conditions.

In the Comparable Market Method the hypothetical condition is less critical, because they differentiate the independent features in which water is involved. In the market comparable method of validation, the comparable subjects are identified with rainfed characteristics directly without changing the physical characteristics of the soil or, changing the type of agricultural production.

In the case of Profit Productivity method generated values are directly related to the production capacity of the property. In this method, it was studied for the current condition, compared with the average productivity of the area under rainfed condition (no water availability).

The factor being evaluated is not the land value but the type of business presented in the property, with all the assets fully working. In this method the water adds value to the property and changes with the amount of production according to the new use. The obtained results can be observed.

Similar to previous methods, in this case we observe a significant variation in the value of the land due to the availability of water, which, under a semiarid environment, is directly related to a higher level of productivity. The values of land productivity were $\$ 2120 \mathrm{USD} / \mathrm{Ha}$ for the Toreador site, $\$ 380 \mathrm{USD} / \mathrm{Ha}$ for the Luz de Maria site, and $\$ 86 \mathrm{USD} / \mathrm{Ha}$ for the Zamarripa site. The relative magnitude of these values behaves similar to the valuation determined by the mass appraisal method, which due to high productivity, is associated with favorable conditions that determine the agricultural capacity. In comparison to the hypothetical condition, the generated values for the current conditions are of higher magnitude. The most distinguished difference was found for the Toreador site, with a decline of $\$ 65 \mathrm{USD} / \mathrm{Ha}$. In the case of the Luz de Maria site, the value for the rainfed condition was \$22 USD/Ha and that of the Zamarripa site was \$25 USD/Ha.

In fact, in the case of the Toreador site, the value for the current condition is approximately $97 \%$ greater than in the degraded hypothetical condition. In the Luz de Maria site, the value determined for the current condition was $94 \%$ higher than the degraded hypothetical condition. Finally, the value for the Zamarripa site was $71 \%$ higher than in the degraded situation.

It is important to note that the difference in value among the property in the current condition with limited water and that of a rainfed hypothetical situation is not very significant; this indicates that the lack of water will reduce the productivity, and therefore generated values will tend to reflect a lower limit.

The highly significant decrease in property value of a Toreador site was due to the fact that in the current condition adequate technology is used to archive great water efficiency use, turning it into a property without limitation of this resource, highlighting the case as an example of intensive agriculture and good water management that we should aim in agriculture.

The production difference in among the various properties has to do with the productive capacity of the study sites, which is directly affected by the available water, but social and political situations of infrastructure can also contribute to the difference. Proximity to urban areas may be another factor involved in the results indirectly.

In the case of the Income Capitalization Method the values obtained for the current and for the hypothetical condition conditions are presented in Table 1. Compared to the results of the other methods, the table shows a similar pattern in the data, especially the Profit Productivity Method as a result of the capitalization of future projection of the field investment. Thus, in the current state, the property value of the Toreador site was $\$ 2540$ USD/Ha, compared with \$319 USD/Ha for the Luz de Maria site and \$26 USD/Ha for the Zamarripa site. In the Toreador site, the value for the current condition is approximately $96 \%$ greater than the degraded hypothetical condition. In the Luz de Maria site, the value determined for the current condition was $91 \%$ higher than the degraded hypothetical condition. Finally, the value for the Zamarripa site was $71 \%$ greater than in the degraded situation.

As with previous methods, the hypothetical rainfed condition reduced the value of the property in all subjects, which indicates the importance of water availability in the value of the land. 
It is important to note that the generated data for the Income Capitalization Method is very similar to that generated by Profits Productivity Method. Since the analysis was done with the same historical data, the Profit Productivity Method is based on a retrospective analysis of the production, while the income capitalization method considers a future projection using the same risk rate as the discount rate risk. In the hypothetical rain-fed season condition, both methods converge to the minimum threshold for the production in semiarid areas.

The comparison between the generated values for each of the four methods under both evaluated conditions is presented in Figure 4. Though necessary, testing the sensitivity that exists in each case with respect to irrigating water availability is not the only factor affecting the value. It is shown that the absence or scarcity of water would limit the possibility of other factors such as technology to increase production and, therefore, the value in either case would also be limited.

The percentages of decrease in each site under the 4 different methods are shown in Table 2, The reduction in property value was inversely proportional to the amount of irrigation water available, as compared to the hypothetical condition when rainfall water is the only source.

Table 2. Percentage reduction in the value for rural property under two different conditions

\begin{tabular}{ccccc}
\hline Rural Property & $\begin{array}{c}\text { Points } \\
\text { reduction }\end{array}$ & $\begin{array}{c}\text { Market } \\
\text { Reduction }\end{array}$ & $\begin{array}{c}\text { Productivity } \\
\text { Reduction }\end{array}$ & $\begin{array}{c}\text { Capitalization } \\
\text { Reduction }\end{array}$ \\
\hline Toreador & $76 \%$ & $79 \%$ & $97 \%$ & $97 \%$ \\
Luz de María & $48 \%$ & $73 \%$ & $94 \%$ & $91 \%$ \\
Zamarripa & $44 \%$ & $14 \%$ & $71 \%$ & $71 \%$ \\
\hline
\end{tabular}

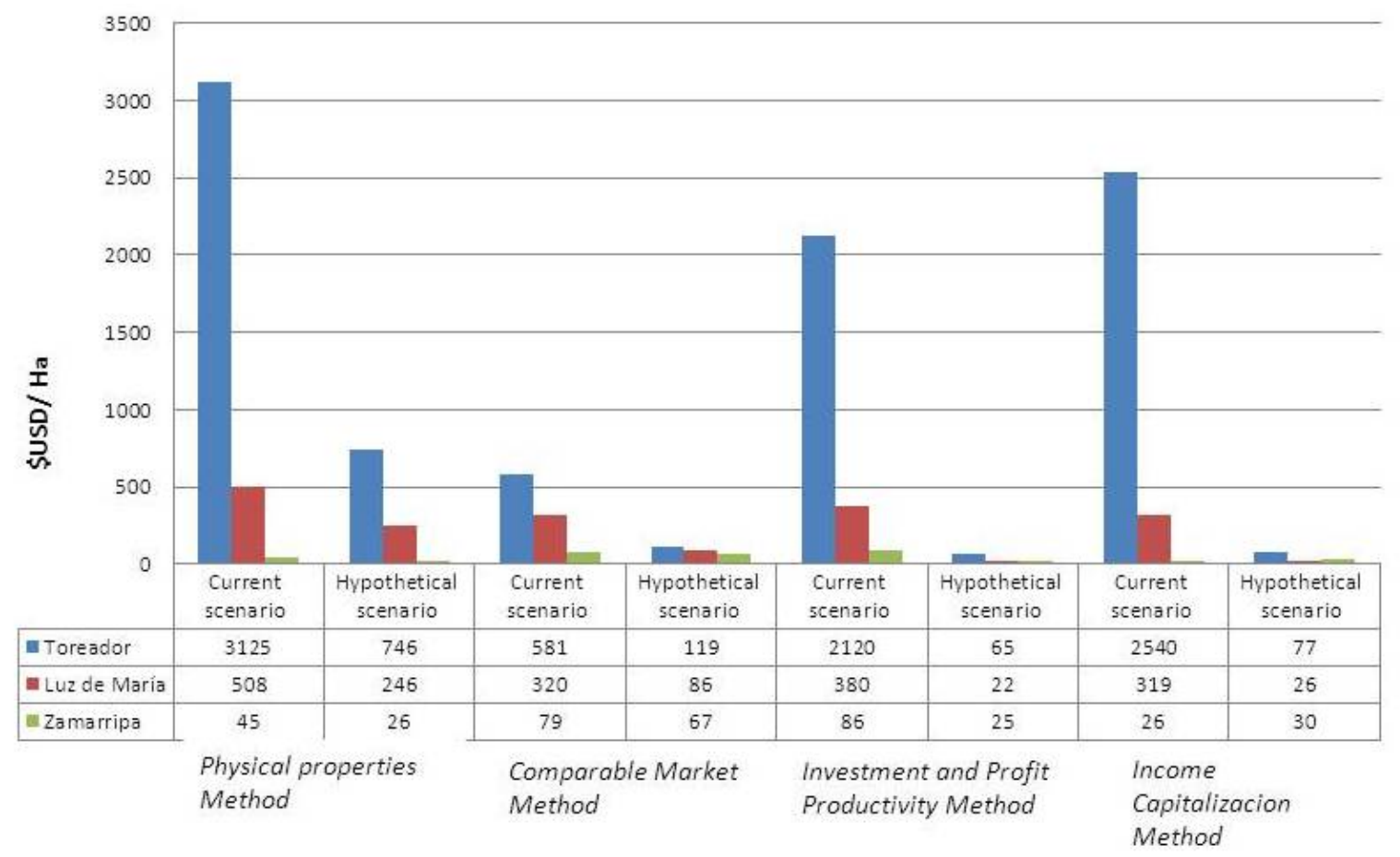

Figure 4. Decrease in value in agricultural properties derived from water availability 


\section{Concluding Remarks}

Results obtained in the study show the significance of water accessibility in the value of rural properties in all the methods used.

In the Market Method which responds to prices offered and the transactions within the area under an open market, the difference in value due to water availability for irrigation was up to $70 \%$. The reduction of price went down from $\$ 582$ USD/Ha to $\$ 119$ USD/Ha in El Toreador, and from \$320 USD/Ha to \$86 USD/Ha in Luz María. Currently, this is the most widely used method to determine the value of rural properties, and since it is capable of determining differences due to water accessibility, it is recommended as a reference method.

However, this method cannot evaluate the sensitivity to water availability when an open market does not exist. That is the case of Zamarripa site, where the lack of an open market is reflected in the reduction of the property value by only $15 \%$ with no water for irrigation, corresponding to a drop in the price from $\$ 79 \mathrm{USD} / \mathrm{Ha}$ to $\$ 68$ $\mathrm{USD} / \mathrm{Ha}$ as a result of the combination of poor accessibility and greater distance to the nearest town. The differential value in the physical mass market method was similar to the market approach. The price of land in El Toreador decreased by $76 \%$ under the scenario of no water available, which corresponds to a price reduction from $\$ 3126 \mathrm{USD} / \mathrm{Ha}$ to $\$ 746 \mathrm{usd} / \mathrm{Ha}$. The other sites showed an average reduction of $45 \%$, with property values dropping from \$508 USD/Ha to \$265 USD/Ha in Luz de Maria and from \$45 USD/Ha, to \$26 USD/Ha in Zamarripa. The difference was significant and shows the sensitivity of the value of properties as indicated by the price when water for irrigation was not available.

The productivity and capitalization methods also showed produced changes in value with trends similar to the other methods. However, it is important to state that the obtained values do not reflect the real value of the property but the business potential at each site.

Availability of water for irrigation plays an important role in defining the price of rural properties and the differential value is proportional to the actual water available. However, other factors such as physical characteristics of the land; proximity to urban centers; accessibility; operation and maintenance; turnover and water user associations; rehabilitation and modernization of systems; increasing competition for available water with other sectors/users; trade and commodity pricing; are also important factors which modify the market price.

\section{References}

Asociación Nacional de Institutos Mexicanos de Valuación, A. C. (1996). Normas Profesionales de Valuación. Toluca, México.

Baylis, K., Feather, K., Padgitt, M., \& Sandretto, C. (2002). Water-based recreational benefits of conservation programs: The case of conservation tillage on US cropland. Review of Agricultural Economics, 24(2), 384-393. http://dx.doi.org/10.1111/1467-9353.00104

Bocquet, D., Chatzis, K., \& Sander, A. (2008). From free good to commodity: Universalizing the provision of water in Paris (1830-1930). Geoforum, 39(6), 1821-1832. http://dx.doi.org/10.1016/j.geoforum.2008.09.07

Chettri, R., \& Venkatesan, R. (1983). Water resource pricing: Policy options. Resources Policy, 9(4), 288-295. http://dx.doi.org/10.1016/0301-4207(83)90005-3

Flores-Benítez, E., Galván-Ruiz, M., \& Ventura-Ramos, E. (2011). Valuación de predios rurales por el método de productividad en función del aprovechamiento del recurso agua. In G. Herrera (Ed.), Tendencias en Ingeniería, Tecnología y Sociedad (p. 290). México: Alfaomega.

French, N. (2003). The Valuation of Specialized Property. A review of Valuation Methods. Berkshire, UK: University of Reading Business School.

French, N. (2007). Valuation uncertainty, Common Professional Standards and Methods. 13th Pacific- Rim Real Estate Society conference (pp. 1-21). Fremantle, Australia.

Friedman, D. (1990). Price Theory: An Intermediate Text. Cincinnati, OH: South-Western Publishing Co.

Gobierno del Estado de Querétaro. (2005). Valor Unitario por Hectárea, base para predios rústicos 2006. Querétaro, México: La Sombra de Arteaga.

Gómez, J., \& Riesgo, L. (2004). Irrigation water pricing: differential impacts on irrigated farms. Agricultural Economics, 31(1), 47-66. http://dx.doi.org/10.1016/j.agecon.2003.02.01

Han, H., \& Zhao, L. (2007). The Impact of Water Pricing Policy on Local Environment - An Analysis of Three Irrigation Districts in China. Agricultural Sciences in China, 6(12), 1472-1478. http://dx.doi.org/10.1016/s1671-29 27(08)60010-3 
IVSC. (2011). International Valuation Standards. UK: IVSC.

Jefferies. (2009). A Short History of income Property Valuation Models, The 17th to 21th Century. European Real State Society Conference. Stockholm, Sweden.

Jerome, G., Robinson, D., \& Youngman, J. (2000). Traditional Methods and New Approaches to Land Valuation. Land Lines.

MacDonald, D., Crossman, N., Mahmoudi, P., Taylor, L., Summers, D., \& Boxall, P. (2010). The value of public and private green spaces under water restrictions. Landscape and Urban Planning, 95(4), 192-200. http://dx.doi.org/10.1016/j.landurbplan.2010.01.003

Madureira, L., Rambonilaza, T., \& Karpinski, I. (2007). Review of methods and evidence for economic valuation of agricultural non-commodity outputs and suggestions to facilitate its application to broader decisional contexts. Ecosystems \& amp; Environment, 120(1), 5-20. http://dx.doi.org/10.1016/j.agee.2006.04.015

Mitra, S., \& Boussardb, J. (2012). A simple model of endogenous agricultural commodity price fluctuations with storage. Agricultural Economics, 43, 1-15. http://dx.doi.org/10.1111/j.1574-0862.2011.00561.x

Palmquist, R. (2005). Chapter 16, Property Value Models. In K. Mäler, \& J. Vincent (Eds.), Handbook of Environmental Economics (pp. 2, 763-819). Elsevier.

Sarmiento, S. (2006). Agua y precios. Reforma.

Secretaría de Economía. (2007). Norma Mexicana de Servicios de Valuación. NMX-C-459-SCFI-ONNCCE2007. México: Diario Oficial de la Federación.

Shively, G. (2001). Agricultural Change, Rural Labor Markets, and Forest Clearing: An Illustrative Case from the Philippines. Land Economics, 77(2), 268-284. http://dx.doi.org/10.3368/le.77.2.268

Smith, V. (1987). Uncertainty, benefit-cost analysis and the treatment of option value. Journal of Environmental Economics and Management, 14(3), 283-292. http://dx.doi.org/10.1016/0095-0696(87)90021-0

Sutton, P., \& Constanza, R. (2002). Global estimates of market and non market values derived from nighttime satellite imagery, land cover, and ecosystem service valuation. Ecological Economics, 41, 509-527. http://dx.doi.org/10.1016/S0921-8009(02)00097-6

Toy, J., Foster, G., \& Renard, K. (2002). Soil erosion: processes, prediction, measurement, and control. New York: John Wiley \& Sons.

Trigeorgis, L. (1993). The Nature of Option Interactions and the Valuation of Investments with Multiple Real Options. Journal of Financial and Quantitative Analysis, 28(1), 1-26. http://dx.doi.org/10.2307/2331148

United Nations. (1992). The Dublin Statement on Water and Sustainable Development. Dublín, Ireland: UN.

United Nations General Assembly. (2010). Resolution adopted by the General Assembly 64/292. The human right to water and sanitation. New York: UN.

Varela-Ortega, C., Sumpsi, J., Garrido, A., Blanco, M., \& Iglesias, E. (1998). Water pricing policies, public decision making and farmers' response: implications for water policy. Agricultural Economics, 19(1-2), 193-202. http://dx.doi.org/10.1016/50169-5150(98) 00048-6

Ventolo, W., \& Williams, M. (2008). Fundamentals of Real Estate Appraisal (10th Ed.). New York: Kaplan Publishing.

Zwarteveen, M. (1997). Water: from basic need to commodity. World Development, 25(8), 1335-1349. http://dx.doi.org/10.1016/S0305-705x(97)00032-6

\section{Copyrights}

Copyright for this article is retained by the author(s), with first publication rights granted to the journal.

This is an open-access article distributed under the terms and conditions of the Creative Commons Attribution license (http://creativecommons.org/licenses/by/3.0/). 